\title{
Regionalisms and Imperialisms in the Making of the Russian Far East, 1903-1926
}

\author{
Ivan Sablin and Daniel Sukhan
}

There was no definitive boundary between Siberia and the Far East in the Russian Empire at the turn of the twentieth century. ${ }^{1}$ The territories between Lake Baikal and the Pacific coast (hereafter simply "east of Baikal") included several overlapping regions (see Figure 1). There was Transbaikalia (Zabaikal'e), the Amur region (Priamur'e) along the Amur River, and the Maritime region (Primor'e) encompassing the southern part of the Russian coast. Priamur'e could also refer to the two easternmost oblasts (provinces with simpler apparatus compared to gubernias) or to all three of them, since the administrative Transbaikal, Amur, and Maritime Oblasts made up the Priamur General Governorship. Furthermore, the whole area still belonged to Siberia encompassing Russian North Asia in common understanding, while the term Far East could refer to both the Russian-controlled part of the Pacific littoral and the larger Asia-Pacific macroregion of China, Korea, Japan, Siam, and French Indochina. The brief existence of the Viceroyalty of the Far East (1903-05), which included both the Priamur General Governorship and Russia's leaseholds in Manchuria, introduced the term Far East to the imperial governance structure but did not consolidate the boundaries of the new region. In 1922, the existence of the Russian Far East as a clearly defined region was already out of question. The formation of the macro-regional administrative division-the Far Eastern Oblast of the Transbaikal, Amur, Maritime, Sakhalin, and Kamchatka Gubernias consolidated the place of the Russian Far East in administrative and symbolic geography of the Soviet Union and the Russian Federation. ${ }^{2}$

Russian nationalism - both imperial and ethnic-proved a major factor in the region's history between 1903 and $1926 .{ }^{3}$ Its brief independence as the Far Eastern Republic (FER), which in 1920-22 claimed a territory similar to that of the Viceroyalty (without the territories ceded to Japan), was presented by the Bolsheviks as a diplomatic maneuver intended for keeping the region for a Russian (rather than Soviet) state in view of the Japanese military intervention (1918-25). The significance of Russian nationalism, however, does not explain the formation of the macro-regional division after the FER was abolished in 1922. Acknowledging the importance of nationalism for the making of the region, this article argues that regionalist and imperialist discourses and

1. The boundary between Siberia and European Russia had been by then firmly set in the administrative sense following the establishment of the Siberian General Governorship (1802) and its division into eastern and western parts (1822). Still, the Urals made the symbolic boundary a zone rather than a line.

2. The latter two oblasts were detached from the Maritime Region in 1909 and transformed into gubernias in 1922.

3. For the discussion of imperial nationalism centered on the idea of a unified Russian state, see Ilya Gerasimov, Jan Kusber, and Alexander Semyonov, eds., Empire Speaks out: Languages of Rationalization and Self-Description in the Russian Empire (Leiden, 2009). 


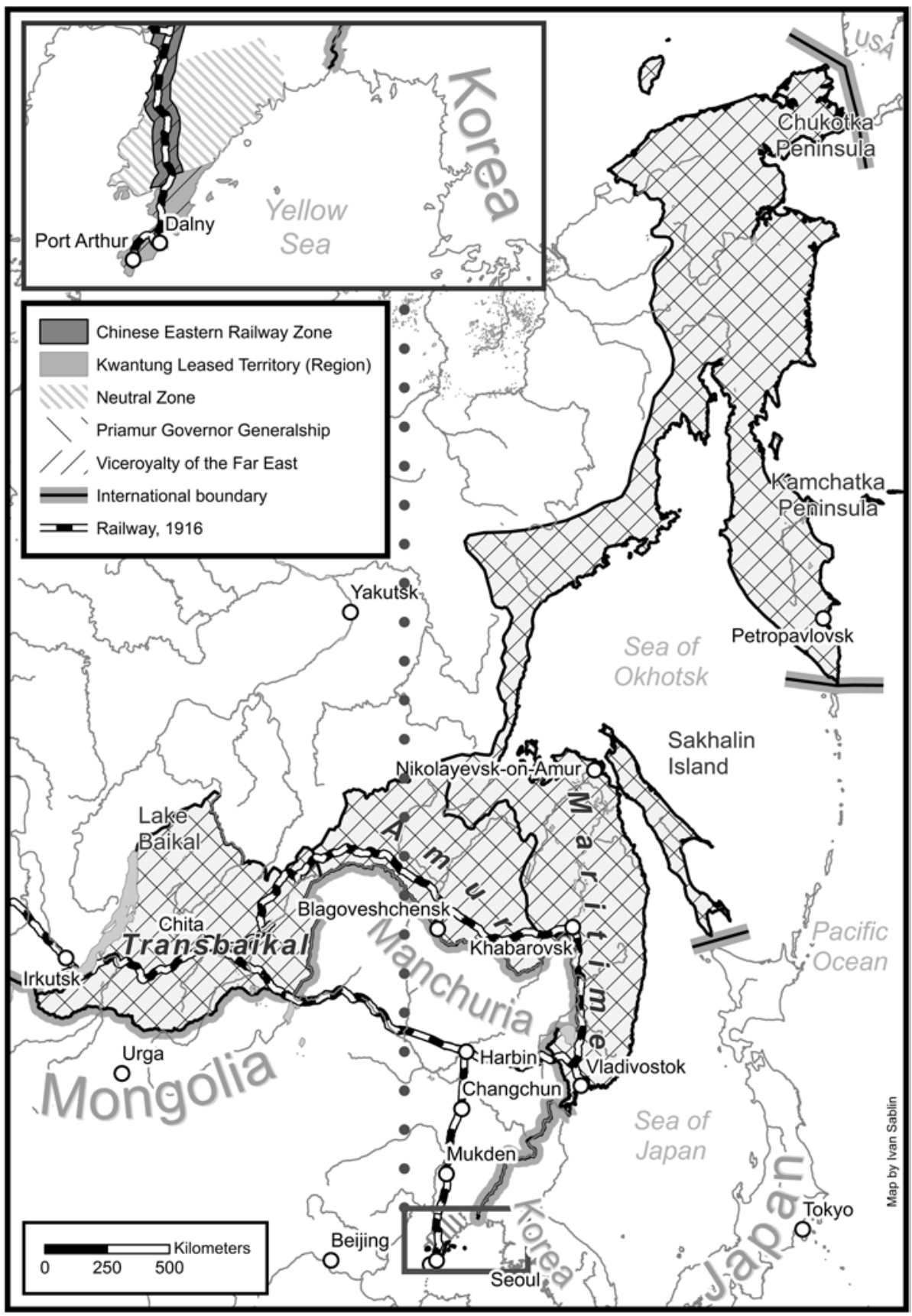

Figure 1. A map of the Russian Far East in 1898-1904. Compiled and designed by Ivan Sablin. 
policies also contributed to the conceptual and administrative formation of the Russian Far East as a post-imperial region during the longer transformation of the Russian Empire/Soviet Union.

Similar to the Siberian Regionalists (Oblastniki), who campaigned for economic and administrative autonomy of Russia's North Asia between the Urals and the Pacific, the Far Eastern educated strata envisioned the territories along the Amur and the Ussuri as a space for economic and even political experimentation and occasionally criticized the imperial center for its policies east of Baikal. ${ }^{4}$ In the early twentieth century, this proto-regionalism collided with imperialism, with Aleksandr Nikolaevich Rusanov and other Far Eastern deputies in the State Duma rebuking the expansion into Manchuria at the expense of Priamur'e and demanding duty-free trade (abolished in 1909) and rural (zemstvo) self-government for the region. Yet it did not develop a consistent intellectual or political program until the Revolution of 1917. The deputies joined the Siberian caucus despite occasionally calling themselves "Far Easterners."

During the Revolution of 1917 and the Civil War (1917-22), Far Eastern regionalism emerged as a radical decentralization policy rather than a coherent intellectual discourse. Even though Rusanov, then appointed Commissar of the Provisional Government for the Far East, launched the debates of a separate post-imperial region in 1917, it was the Bolshevik Aleksandr Mikhailovich Krasnoshchekov, a native of Ukraine and a 1917 remigrant from the USA, who proved essential for the making of the region. Even though his regionalism did not find many supporters either within or outside his party, with the absolute majority of Bolshevik and anti-Bolshevik politicians remaining nationalistically inclined, Krasnoshchekov made the step from discussing the region as different from the rest of Siberia and Russia, to declaring its de facto autonomy as the Soviet Republic of the Far East in 1918 and then its formal independence as the FER in 1920.

As Aleksandr Azarenkov had shown, it was Krasnoshchekov's regionalism rather than Vladimir Il'ich Lenin's pragmatism that proved crucial for the making of the FER. The region's belonging to Russia was indeed contested

4. Appealing to the decentralization discourses of the Decembrists and the first generation of Russian socialist intellectuals, Siberian Regionalism (Oblastnichestvo) can be dated back to the 1850s and 1860s when Siberian students, including Grigorii Nikolaevich Potanin and Nikolai Mikhailovich Iadrintsev, formed a regional circle in Saint Petersburg for discussing the future of Siberia. In 1865 many of them were arrested, tried for "separatism," and sentenced to imprisonment or exile. Politically, Siberian Regionalists were close to the socialist Populists (Narodniki) in the 1870s and 1880s, with many finding liberalism more appealing since the 1890s. For an overview of regionalist discourses in the Russian Empire in general and Siberia in particular, see Mark Von Hagen, "Federalisms and Pan-Movements: Re-Imagining Empire," in Jane Burbank, Mark von Hagen, and Anatolyi Remnev, eds., Russian Empire: Space, People, Power, 1700-1930 (Bloomington, 2007), 494-510; Aleksei Miller, The Ukrainian Question: The Russian Empire and Nationalism in the Nineteenth Century (Budapest, 2003); I. L. Dameshek and A. V. Remnev, Sibir' v sostave Rossiiskoi imperii (Moscow, 2007). For the discussions of Far Eastern proto-regionalism, see Mark Bassin, Imperial Visions: Nationalist Imagination and Geographical Expansion in the Russian Far East, 1840-1865 (Cambridge, 2006); John J. Stephan, The Russian Far East: A History (Stanford, 1994), 93-98. 
by the Allied Intervention, with the Japanese, Czechoslovaks, and Americans each still having strong military presence east of Baikal in early 1920. The formation of a nominally independent state was just one option, however, which in fact was vigorously opposed by many regional Bolsheviks. Krasnoshchekov personally convinced the Moscow leadership that the existence of the FER was necessary. Furthermore, during his brief tenure as the head of the republic's administration, Krasnoshchekov tried to make it autonomous in real terms. ${ }^{5}$

Krasnoshchekov's regionalism was closely connected to the idea of creating a new empire-hierarchical governance for multiethnic, multireligious, and otherwise socially-diverse populations of Northern Eurasia-with the Bolshevik Party at the center. Formally, this empire was confined to the Soviet ethno-national federation. ${ }^{6}$ Informally, it sought to become global through the World Revolution. Even after "Socialism in One Country" substituted the World Revolution as the guiding principle of Bolshevik empire building in 1924-26, creating informal foreign dependencies remained on the agenda. This expansionism under the guise of national and class liberation made the Bolsheviks pioneers of the policy and discourse of the "new imperialism."”

Krasnoshchekov's project of the Russian Far East as an outpost of Bolshevik influence in East Asia was reminiscent of the expansionist ideas that brought the Viceroyalty into being but abandoned the idea of Russian domination. In 1918, Krasnoshchekov attempted to include the Chinese and Koreans into what he retrospectively called the "Far Eastern Federation." In 1920-21, the FER competed with the Communist International (Comintern) for leadership in Bolshevik East Asian policies. Although Krasnoshchekov failed to defend his vision and was removed from office, the idea of a Far Eastern macro-region within the Bolshevik imperial structure outlived the FER.

Krasnoshchekov's policies were a specific way of navigating the political and economic crises of the Revolution and the Civil War. The slogans of decentralization were mainstream in 1917, which allowed Ilya Gerasimov to speak of "the Great Imperial Revolution." sense part of the larger post-imperial trend, which involved minority nationalist, federalist, and regionalist debates in Ukraine, Siberia, Northern Russia,

5. A. A. Azarenkov, "Demokraticheskii kompromiss": Ideia "bufera" na Dal'nem Vostoke $v$ planakh i taktike politicheskikh sil-uchastnikov grazhdanskoi voiny $v$ Rossii, ianvar' 1920-ianvar' 1921 gg. (Komsomolsk-na-Amure, 2001); A. A. Azarenkov, Politicheskaia model' Dal'nevostochnoi respubliki: Mekhanizm funktsionirovaniia institutov vlasti "bufernogo" gosudarstva, 1920-1922 gg. (Komsomolsk-na-Amure, 2001); T. A. Ornatskaia and Iu. N. Tsipkin, "Kontsessionnaia politika Dal'nevostochnoi respubliki, 1920-1922 gg.," Rossiia i ATR, no. 1 (2007): 5-20.

6. Ilya Gerasimov et al., "In Search of a New Imperial History," Ab Imperio, no. 1 (2005): 33-56; Ronald Grigor Suny and Terry Martin, "Introduction," in Ronald Grigor Suny and Terry Martin, eds., A State of Nations: Empire and Nation-Making in the Age of Lenin and Stalin (Oxford, 2001), 3-20.

7. Prasenjit Duara, “The Imperialism of 'Free Nations': Japan, Manchukuo and the History of the Present," in Ann Laura Stoler, Carole McGranahan, and Peter C. Perdue, eds., Imperial Formations (Santa Fe, 2007), 211-39.

8. Ilya Gerasimov, “The Great Imperial Revolution,” Ab Imperio, no. 2 (2017): 21-44. 
the Urals, Central Asia, and other parts of the former empire. ${ }^{9}$ Unlike most others, the case of the Far East highlights a Bolshevik approach to regionalist (rather than ethno-nationalist) decentralization and therefore has potential to contribute to studies of the imperial transformation. ${ }^{10}$

\section{Imperial Legacies}

The creation of the Viceroyalty of the Far East seemed to crown the more than three centuries of Russia's expansion to North Asia and its increasing involvement in East Asian politics since the Amur Acquisition of 1858-60. At the same time, Saint Petersburg's attention to Manchuria and Russia's defeat in the Russo-Japanese War (1904-5) met with increasing criticism among regional intellectuals nourishing an anti-imperialist proto-regionalism.

Modern international boundaries in the northern Pacific took their shape in the nineteenth century through conflicts and negotiations between neighboring imperial formations-the Russian Empire, the Qing Empire, Japan, and the USA. Large areas controlled or contested by the Qing Empire were recognized as Russian in the Treaties of Aigun and Tianjin (1858), and the Convention of Beijing (1860), while the cession of Alaska to the USA (1867) and the first Russo-Japanese agreements (1855 and 1875) set the new maritime boundaries. The formation of the Transbaikal (1851), Amur (1859), and Ussuri (1860) Cossack Hosts and the establishment of new outposts turned townsNikolayevsk-on-Amur (1850), Blagoveshchensk (1856), Khabarovsk (1858), and Vladivostok (1860) - and settler colonialism accompanied the expansion. The Amur gave this part of Siberia its first commonly used name-the Priamur krai (territory) or Priamur'e. In 1884, the Transbaikal, the Amur, and the Maritime Oblasts were united into the Priamur General Governorship. In 1885, the term "Far East" started to be used in relation to Priamur'e and the southern part of the administrative Maritime Oblast (Primor'e). ${ }^{11}$ Yet, Russia's maritime ambition did not translate into a strong foothold. In the 1880s, the region was deemed a mere colony still awaiting settlement and economic exploitation. ${ }^{12}$

9. I. V. Narskii, Zhizn' v katastrofe: Budni naseleniia Urala v 1917-1922 gg. (Moscow, 2001); Liudmila Novikova, Provintsial'naia "Kontrrevoliutsiia": Beloe Dvizhenie i grazhdanskaia voina na russkom Severe, 1917-1920 (Moscow, 2011); Tanja Penter, Odessa 1917: Revolution an der Peripherie (Cologne, 2000); N. G. O. Pereira, White Siberia: The Politics of Civil War (Montreal, 1996); Ronald Grigor Suny, The Revenge of the Past: Nationalism, Revolution, and the Collapse of the Soviet Union (Stanford, 1993); Von Hagen, "Federalisms and Pan-Movements: Re-Imagining Empire.”

10. Willard Sunderland, "The USSR as a Multinational State from the Revolution to the Death of Stalin: Western Scholarship since 1991," Vestnik of Saint Petersburg University: History, no. 4 (2016): 142-58.

11. Pravila perevozki tovarov na parokhodakh obshchestva dobrovol'nogo flota, a ravno tovarov priamogo cherez Odessu soobshcheniia mezhdu Moskvoi i portami Dal'nego Vostoka: S1-go ianv. 1885 g. (Saint Petersburg, 1885); F. F. Shperk, Rossiia Dal'nego Vostoka, Zapiski Russkogo geograficheskogo obshchestva 14 (Saint Petersburg, 1885).

12. A. V. Remnev, Rossiia Dal'nego Vostoka: Imperskaia geografia vlasti XIX-nachala XX vekov (Omsk, 2004), 142, 281, 290-91; Stephan, The Russian Far East: A History, 27, 41-49. 
The construction of the Trans-Siberian Railway, which began in 1891, became emblematic of railway imperialism, which involved the acquisition of extraterritorial possessions instead of direct annexations. ${ }^{13}$ Saint Petersburg ensured the Chinese Eastern Railway (CER) concession in 1896 and the Guandong (Kwantung) Leasehold in 1898. The center's attention shifted from Priamur'e and Primor'e to Manchuria. Regional officials were hostile to the perceived disregard for the Priamur General Governorship and opposed the construction of the railway through Manchuria. The subordination of Priamur'e to Port Arthur in the new Viceroyalty, however, made Saint Petersburg's priorities clear. ${ }^{14}$ Imperialism introduced the term Far East to governance and proved the special status of the region in the making. Viceroy Evgenii Ivanovich Alekseev had full military and civil authority in the region and supervised diplomatic relations. Yet, the Viceroyalty did not survive the Russo-Japanese War: Alekseev was released from his position in $1905 .{ }^{15}$

The railway facilitated settler colonialism in Priamur' $e$, attracting numerous newcomers from the European part of the Russian Empire, Korea, and the Qing Empire. Duty-free trade stimulated the development of Russian and foreign business. By 1897, the combined population of the Transbaikal $(672,037)$, Amur $(120,306)$, and Maritime $(223,336)$ Oblasts surpassed one million. Despite the abolition of the duty-free regime (first in 1900-04 and ultimately in 1909) and insufficient public investment, the population of the Russian Far East continued to grow. Ukrainians $(350,000)$, Koreans $(110,480)$, indigenous Buryat-Mongols $(108,800)$ and Chinese $(100,000)$ made up considerable minorities among the estimated 2,000,000 people in 1922-23. ${ }^{16}$

International commentators recognized Russia's involvement in the Far Eastern Question at the turn of the twentieth century. ${ }^{17}$ Still, Priamur'e was part of Siberia rather than the larger Far East for domestic observers. The early volumes of the Brockhaus and Efron Encyclopedic Dictionary did not feature the term Far East. Vladivostok was called a city in East Siberia. ${ }^{18}$ The supplementary volumes introduced the Far East as a "geographic name that became used over the past years when the attention of Europeans was directed at the

13. Steven G. Marks, Road to Power: The Trans-Siberian Railroad and the Colonization of Asian Russia, 1850-1917 (Ithaca, 1991).

14. Stephan, The Russian Far East: A History, 57-61.

15. A. V. Milezhik, "Dal'nevostochnoe namestnichestvo kak popytka reformy regional'nogo upravleniia, 1903-1905 Gg.," Vestnik Dal'nevostochnogo otdeleniia Rossiiskoi akademii nauk, no. 3 (2007): 110-15.

16. Institut demografii Natsional'nogo issledovatel'skogo universiteta Vysshaia shkola ekonomiki, "Pervaia Vseobshchaia perepis' naseleniia Rossiiskoi imperii 1897 g.," accessed December 1, 2015, http://demoscope.ru/weekly/ssp/census.php?cy=0; Ivan Sablin, "National Autonomies in the Far Eastern Republic: Post-Imperial Diversity Management in Pacific Russia, 1920-1922," History and Anthropology 28, no. 4 (2017): 450.

17. Thomas F. Millard, The New Far East: An Examination into the New Position of Japan and Her Influence upon the Solution of the Far Eastern Question, with Special Reference to the Interests of America and the Future of the Chinese Empire (New York, 1906), 1-2.

18. K. K. Arsen'ev and F. F. Petrushevskii, eds., "Vladivostok," in Entsiklopedicheskii slovar' Brokgauza i Efrona (Saint Petersburg, 1892), 11:625-26. 
destiny of China" and acknowledged that for Russia it gained importance only after the "occupation of Kwantung and Manchuria."19

The inter-imperial Far Eastern Question included explicit connotations to the western civilizing mission and the racialized discussions of "yellow labor," which had much potential in the global economy, and "yellow peril," which ostensibly endangered European civilization. Korean settlement and Chinese labor migration, the western effort to put down the Boxer Rebellion (1899-1901), involving the massacre of thousands of Chinese in Blagoveshchensk, and the Japanese expansion after the Qing-Japanese War (1894-95) stimulated the latter. In this context, the Trans-Siberian Railwayand the nascent Russian Far East in general-was supposed to become a channel for Europeanization. ${ }^{20}$

Yet the Russo-Japanese War manifested the failure of Russian imperialism in the region and contributed to the First Russian Revolution (1905-07). During the revolution, oppositional intellectuals (including exiles) brought about the idea of possible autonomy for the Ussuri Krai but the lack of interest among townsmen and peasants made the discussions marginal. ${ }^{21}$

The creation of the imperial State Duma during the revolution fueled the discussions of decentralization. Although Priamur deputies missed the heated debates in the First (1906) and Second (1907) Dumas, all of them became part of liberal or socialist opposition and joined the Siberian caucus in the Third (1907-12) and Fourth (1912-17) Dumas. The Siberian caucus was one of the many regional, social estate, and minority national groups campaigning for special rights in a reformed empire. Political parties put forward their decentralization projects in dialogue with the many imperial groupings. The Socialist Revolutionaries (SRs) backed the idea of national-territorial and regional autonomy. The liberal Constitutional Democrats (KDs) did not envision minority national territories, apart from Finland and Poland, but advocated redistribution of competence between the center and the regions. ${ }^{22}$

Like in the cases of other imperial peripheries, the Duma debates helped Far Eastern deputies-who occasionally called themselves Far Easterners (dal'nevostochniki)-articulate distinct regional interests. Andrei Ivanovich Shilo, a prosperous peasant of Ukrainian origin, Aleksandr Rusanov, and others criticized Saint Petersburg's policies in Priamur'e, from the abolition of duty-free trade to excessive militarization to the inadequate treatment of settlers. Yet this criticism remained within the scope of Siberian Oblastnichestvo and the left-liberal (moderate socialist and liberal) attempts to introduce better

19. K. K. Arsen'ev and V. T. Sheviakov, eds., "Dal'nii Vostok," in Entsiklopedicheskii slovar' Brokgauza i Efrona (Saint Petersburg, 1905), 1a:653-54.

20. Chia Yin Hsu, “A Tale of Two Railroads: 'Yellow Labor,' Agrarian Colonization, and the Making of Russianness at the Far Eastern Frontier, 1890s-1910s," Ab Imperio, no. 3 (2006): 217-53; Robert E. Lewis, The Educational Conquest of the Far East (New York, 1903).

21. M. A. Kudrzhinskii, "Vladivostok v 1905 g.: Iz nabliudenii ochevidtsa, Part 3," Minuvshie gody, no. 7 (1908): 33.

22. Rustem Tsiunchuk, "Peoples, Regions, and Electoral Politics: The State Dumas and the Constitution of New National Elites," in Jane Burbank, Mark von Hagen, and Anatolyi Remnev, eds., Russian Empire: Space, People, Power, 1700-1930 (Bloomington, 2007), 366-97. 
governance. Far Eastern interests did not contradict defensive Russian nationalism and Siberian Oblastnichestvo. Citing the contribution of the North Asian population to the Russo-Japanese War and First World War efforts, regional deputies simply demanded more regional rights in a reorganized empire. ${ }^{23}$

\section{Revolutionary Regionalisms, 1917-1920}

The collapse of the Russian Empire in 1917 brought about both the implementation of decentralization slogans, especially those pertaining to minority nationalisms, and ad hoc political regionalism. During the democratic phase of the revolution, several Far Eastern politicians participated in the congresses of Siberian Oblastniki, while Rusanov led the effort to turn the former Priamur General Governorship into a self-governing region. After the Bolshevik takeover in December 1917, Krasnoshchekov adopted the decentralization discourse and advocated the creation of a Far Eastern unit in a Soviet federation.

The February Revolution of 1917 launched vivid discussions and political activism. Committees of public safety and soviets of workers' and soldiers' deputies emerged in urban centers along the Trans-Siberian Railway. Soldiers and workers-mainly railroaders, dockers, and miners-made up the backbone of socialist parties. The SRs and the Social Democrats, who did not split into Bolsheviks and Mensheviks until September 1917 east of Baikal, formed the moderate socialist mainstream at the first two Far Eastern Krai Congresses of Soviets in the spring and summer of 1917. ${ }^{24}$

Although the Siberian caucus of the State Duma did not transform into a political party, revolutionary self-organization consolidated the Siberian Oblastnichestvo movement. In the summer of 1917, the Provisional Government extended democratic zemstvo self-government to North Asia. The SRs triumphed in municipal and zemstvo elections across Siberia in the summer and fall of 1917. Positioning themselves as an empire-wide peasant party, the SRs also continued to back regionalism and minority nationalism (unlike the KDs who took a much more centrist stance). The SRs were a majority at the Siberian Regional Conference (Tomsk, August 2-9, 1917), which adopted the white and green "national Siberian flag," and at the larger Siberian Regional Congress (Tomsk, October 8-17, 1917), which reaffirmed the right to national and regional autonomy in the future federative Russian republic. The Siberian Regional Congress reaffirmed the integrity of Siberia from the Urals to the Pacific but suggested dividing it into three parts for better governance, with the Transbaikal Oblast joining Eastern Siberia and the four easternmost oblasts (Amur, Maritime, Sakhalin, and Kamchatka) making up the Far East. The Far Eastern press welcomed the Siberian regionalist movement, but the involvement of those from the Far East was marginal: out of the 182 delegates

23. Ivan Sablin, "Towards the First Far Eastern Republic: Regionalism, Socialism, and Nationalism in Pacific Russia, 1905-1918," Higher School of Economics Research Paper WP BRP 142/HUM/2017, 2017.

24. Rossiiskii gosudarstvennyi istoricheskii arkhiv Dal'nego Vostoka (hereafter RGIA DV) (Russian State Historical Archive of the Far East), f. R-2422, op. 1, d. 573, 1. 6-7 (S. Kh. Bulygin, The First Soviets in the Far East, 1917-1918). 
at the congress, only seven represented the Amur and Maritime Oblasts. The campaign for restructuring the empire into a democratic federation was also taking place in Ukraine, and Siberian regionalist organizations established contact with the moderate socialist Ukrainian Central Rada. ${ }^{25}$

As the Commissar for the Far East, Rusanov attempted to launch a separate regionalist movement in the former Priamur General Governorship. Together with other revolutionary leaders, he returned to the issue of duty-free trade. While the Provisional Government demanded that all customs rules be followed, it did satisfy Rusanov's plea to lift duties from imported seeds and backed the initiative of Vladivostok businessmen to discuss the city's possible free-port status. ${ }^{26}$ Most of the ten delegates from soviets and (non-soviet) executive committees to the Far Eastern Krai Conference on the Elections to the Constituent Assembly (Khabarovsk, August 16-17, 1917), which Rusanov convened, discussed regional self-government. They agreed that the Far East only needed economic self-government-practically a territorial ( $k r a e-$ voe) zemstvo above provincial, district, and county levels. Most of them also agreed that Russia was to become a decentralized unitary state rather than a federation. ${ }^{27}$

A different version of Far Eastern regionalism, much closer to its Siberian counterpart, was voiced at the SR-led Second Maritime Oblast Peasant Congress (Nikolsk-Ussuriysky, July 1917). ${ }^{28}$ The congress reaffirmed the slogan of the "democratic federative republic" and instructed its future representatives to demand broad autonomy for regions and nationalities in the Constituent Assembly and ensure that the "Far Eastern periphery" was "singled out into an independent [samostoiatel'nyi], quite autonomous unit." 29

Even though Bolsheviks participated in the Tomsk Siberian Regional Congress, their leadership put forward a different vision of the Russian republic in the fall of 1917. Yet, they also backed the idea of a larger regional unit. Members of the CentralExecutiveCommittee of SiberianSoviets(Tsentrosibir'), which formed at the first All-Siberian Congress of Soviets (Irkutsk, October 16-24, 1917) with the participation of Far Eastern Bolsheviks, claimed the whole territory between the Urals and the Pacific after the Bolshevik coup

25. Dal'nii Vostok, October 6, 1917: 2; K. A. Ankusheva et al., Istoriia obshchestvennogo samoupravlenia $v$ Sibiri vtoroi poloviny XIX-nachala XX veka (Novosibirsk, 2006); I. A. Iakushev, "Fevral'skaia revoliutsiia i sibirskie oblastnye s'ezdy: K istorii oblastnogo dvizheniia v Sibiri," in Volnaia Sibir', vol. 2 (Prague, 1927), 23; Pervyi Sibirskii oblastnoi s'ezd 8-17 oktiabria 1917 goda v g. Tomske: Postanovleniia s'ezda (Tomsk, 1917); V. M. Rynkov, "Organy mestnogo samoupravleniya v antibolshevistskom lagere na vostoke Rossii (seredina 1918-konets 1922 g.)," in Politicheskiye sistemy i rezhimy na vostoke Rossii $v$ period revolyutsii i grazhdanskoy voiny: Sbornik nauchnykh statei, ed. V. I. Shishkin (Novosibirsk, 2012), 125-58.

26. Priamurskie vedomosti, April 6, 1917: 2; Priamurskie izvestiia, April 22, 1917: 5; April 25, 1917: 2; April 27, 1917: 7; May 16, 1917: 5; June 1, 1917: 4; July 13, 1917: 4; July 16, 1917: 4; July 18, 1917: 4.

27. Priamurskie izvestiia, August 6, 1917: 4; August 27, 1917: 3-4; August 29, 1917: 3-4.

28. In late 1905, a similar congress seemed open to the suggestions about an Ussuri autonomy voiced by socialist intellectuals, yet the project was never discussed further due to the suppression of the revolution in early 1906.

29. Priamurskie izvestiia, August 8, 1917: 4. 
in Petrograd, which became known as the October Revolution of 1917. The Council of People's Commissars (Sovnarkom) in Petrograd and Tsentrosibir' in Irkutsk were barely recognized east of Baikal. On November 9, 1917, Rusanov and other moderate socialists issued a proclamation against Bolshevik dictatorship. Even though individual organizations in Vladivostok, Chita, Blagoveshchensk, Harbin, and elsewhere called for transferring all authority to the soviets, such a position was marginal. ${ }^{30}$

Participants at the Extraordinary Siberian Regional Congress (Tomsk, December 6-15, 1917) also opposed the Bolshevik coup stressing the central role of an autonomous "Great Siberia" in rebuilding a democratic state. For the SR majority, however, Siberian Oblastnichestvo had turned into a means of struggle against the Bolsheviks rather than a goal in itself, which alienated conservative and liberal Oblastniki. The SRs nevertheless largely retained their minority nationalist backing. ${ }^{31}$

Just like in many other predominantly rural parts of the empire, the SRs triumphed in the Constituent Assembly elections east of Baikal, although the Bolsheviks did well in Vladivostok. Supporting the initiative of the SR-led Amur Oblast Zemstvo Assembly and refusing to recognize the Petrograd coup, Rusanov convened the First Far Eastern Krai Congress of Municipal and Zemstvo Self-Government (Khabarovsk, December 11, 1917) of three representatives from the Amur Oblast and six representatives from the Maritime Oblast. As Commissar, Rusanov transferred his authority to the six-member Provisional Bureau of Zemstvo and Municipal Authorities, representing the Amur, Maritime, Sakhalin, and Kamchatka Oblasts as well as the Amur and Ussuri Cossack Hosts. The SR Mikhail Ioakimovich Timofeev was elected its provisional chairman before representatives of all self-government bodies assembled for the new congress. The Bureau proclaimed supreme civil authority in the Russian Far East, becoming the first revolutionary Far Eastern government. ${ }^{32}$

Krasnoshchekov, who soon after his arrival from the US became a zemstvo official in Nikolsk-Ussuriysky, was elected to both the Municipal and Zemstvo Congress and the Third Far Eastern Congress of Soviets, which was also about to start in Khabarovsk. The rise of Bolshevik influence in regional soviets in the fall of 1917 allowed Krasnoshchekov to ensure Rusanov's arrest through the Executive Committee of the Khabarovsk Soviet. On December 12,

30. Izvestiia Vladivostokskogo soveta rabochikh $i$ soldatskikh deputatov, November 1 , 1917: 1, 3; November 9, 1917: 1; Priamurskie izvestiia, October 28, 1917: 6; October 29, 1917: 2; October 31, 1917: 2-4; November 2, 1917: 3; November 5, 1917: 2; RGIA DV, f. R-2422, op. 1, d. 573, 1. 13-17 (S. Kh. Bulygin, The First Soviets in the Far East, 1917-1918); S. Tsypkin, A. Shurygin, and S. Bulygin, eds., Oktiabr'skaia revoliutsiia i grazhdanskaia voina na Dal'nem Vostoke: Khronika sobytii, 1917-1922 gg. (Moscow, 1933), 19-25.

31. I. V. Nam, "Natsionalnyi vopros v programmnykh ustanovkakh sibirskikh oblastnikov, zakonotvorcheskoi i politicheskoy praktike Sibirskoi oblastnoi dumy, 1917-ianvar' 1918 gg.," Vestnik Tomskogo gosudarstvennogo universiteta: Istoriia, kraevedenie, etnologiia, arkheologiia, no. 281 (2004): 47-57; M. V. Shilovskii, "Polneishaia samootverzhennaia predannost' nauke": G. N. Potanin, biograficheskii ocherk (Novosibirsk, 2004).

32. Priamurskie izvestiia, December 12, 1917: 3; V. G. Popov, "Pervyi s'ezd zemskikh i gorodskikh samoupravlenii Dal'nego Vostoka,” Sibirskaia zaimka, last accessed January 17, 2017, at http://zaimka.ru/power/popov1.shtml. 
1917, the Third Far Eastern Congress of Soviets opened with a Bolshevik-Left SR majority and elected Krasnoshchekov Chairman. On December 14, 1917, it proclaimed Soviet rule in the Far East. Krasnoshchekov headed the Executive Committee of Far Eastern Soviets (Dal'kom). Dal'kom reserved seats for the Maritime and Amur zemstvos (adding "and Self-Government Bodies" to its name). Open to moderate socialists, Dal'kom did not become subordinate to Tsentrosibir', which was also the case with the People's Council of the Transbaikal Oblast, established by SRs, Mensheviks, and Bolsheviks in late December 1917-early January 1918. 33

The dispersal of the All-Russian Constituent Assembly on January 6, 1918, however, demonstrated that the Bolshevik leadership was not open to compromise. Later that month, the Soviet authorities prevented the convocation of the Siberian Regional Duma of nominated representatives in Tomsk. The SR Ivan Aleksandrovich Iakushev, whom the arriving deputies nominated as chairman, was arrested together with others. Those delegates who escaped arrest managed to gather and form the Provisional Siberian Government under the SR Petr Iakovlevich Derber. In March 1918, Derber's group relocated to Harbin. ${ }^{34}$

Coalitional authorities east of Baikal also did not last. In late Januaryearly February 1918, the Blagoveshchensk Soviet under the leadership of the Bolshevik Fedor Nikanorovich Mukhin, who unlike Krasnoshchekov opposed compromises with zemstvos, proclaimed itself the supreme authority in the Amur Oblast and launched radical reforms featuring the abolition of local self-government and nationalization. Dal'kom, which effectively controlled the area around Khabarovsk, also introduced requisitions, confiscations, and censorship in January-February 1918. The Red Guard of workers and former German and Austro-Hungarian prisoners of war backed the claim of the new Soviet authorities. The Cossacks and soldiers who returned from the front contributed to the suppression of the People's Soviet and zemstvo in the Transbaikal Oblast in February 1918. The Vladivostok Soviet was more moderate due to the international presence-Japanese, American, British, and Chinese ships called in the harbor to guard the remaining military goods in December 1917-January 1918-but also engaged in selective nationalizations. ${ }^{35}$

The policies of Soviet authorities stimulated opposition. The workers of the Amur Steamship Company, for instance, opposed its nationalization, but Dal'kom enforced it anyway. On March 6, 1918, soon after Krasnoshchekov arrived in Blagoveshchensk for participating in the Fourth Amur Oblast Peasant Congress and ensuring Dal'kom's control over the Amur Oblast, the Cossack and volunteer detachments under Ataman of the Amur Cossacks and former State Duma deputy Ivan Mikhailovich Gamov arrested Soviet politicians and took control of the city. The anti-Bolsheviks attempted to create a

33. Izvestiia Vladivostokskogo soveta rabochikh i soldatskikh deputatov, December 20, 1917: 2-3; December 21, 1917: 2; December 30, 1917: 1; RGIA DV, f. R-2422, op. 1, d. 573, 1. 22-23 (S. Kh. Bulygin, The First Soviets in the Far East, 1917-1918); Tsypkin, Shurygin, and Bulygin, Oktiabr'skaia revoliutsiia i grazhdanskaia voina, 29-32.

34. Pereira, White Siberia: The Politics of Civil War, 51-55.

35. RGIA DV, f. R-2422, op. 1, d. 573, 1. 28-33; Ankusheva et al., Istoriia obshchestvennogo samoupravlenia $v$ Sibiri vtoroi poloviny XIX-nachala XX veka. 
coalition authority, but the offensive of the 12,000-strong Red Guard (including many former prisoners of war) under Moisei Izrailevich Gubel'man forced them to retreat into Chinese territory on March 13, 1918. About the same time, the Siberian Soviet forces under Sergei Georgievich Lazo defeated the volunteer detachments under Grigorii Mikhailovich Semenov, a Transbaikal Cossack, in the Transbaikal Oblast pushing them to the CER Zone, which was controlled by General Dmitrii Leonidovich Khorvat, who commanded Russian troops there. ${ }^{36}$

In April 1918, while the Ussuri Cossack Ivan Pavlovich Kalmykov emerged as a new anti-Bolshevik leader in the Maritime Oblast, Semenov launched a new offensive. Foreign representatives defied Soviet authorities in Vladivostok. The attack on the Ishido Company on April 4, 1918, which left two Japanese businessmen dead, prompted the landing of Japanese troops in Vladivostok the next day. Like Russia's other former allies, the Japanese were concerned with the future of the military goods that had accumulated in Vladivostok and the collapse of the Eastern Front after the Soviet-German truce in late 1917 and the Treaty of Brest-Litovsk (March 3, 1918). Regional anti-Bolsheviks welcomed the Japanese landing, while the passive stance of the former proponents of Soviet rule hinted that radical policies had few backers. The Japanese nevertheless did not suppress the Soviet authorities in Vladivostok and retreated to their ship later that month.

The clashes with Cossack leaders and the anticipation of further international action stimulated the attempts of regional Soviet authorities to consolidate their regime. The Third Transbaikal Congress of Soviets (Chita, March 24-April 5, 1918) formed the Transbaikal Oblast Council of People's Commissars under Nikolai Mikhailovich Matveev. The Fifths Amur Oblast Peasant and Cossack Congress (Blagoveshchensk, April 1-10, 1918) went even further and proclaimed the Amur Toilers' Socialist Republic or "the autonomous Amur Socialist Republic" under Mukhin. Finally, in its resolution on nationalization, the Fourth Far Eastern Congress of Soviets (Khabarovsk, April 8-14, 1918) declared the formation of "the Soviet Republic of the Far East.” Although Krasnoshchekov stressed that the Far East belonged to Russia and protested against Japanese imperialism, he called the congress "a constituent assembly" of the new Far East belonging to the toiling people. ${ }^{37}$

The Bolsheviks and their allies in the Transbaikal, Amur, and Maritime Oblasts used the equivocal resolutions of the Third All-Russian Congress of

36. The role of Far Eastern Cossacks in the Russian Civil War was different from that of the other Cossack hosts. Although some of them joined the Far Eastern "atamans" Grigorii Mikhailovich Semenov and Ivan Pavlovich Kalmykov, many supported Bolsheviks. This owed much to the proximity of Far Eastern Cossacks to regional peasants in social terms, see Jamie Bisher, White Terror: Cossack Warlords of the Trans-Siberian (London, 2005); Rynkov, "Organy mestnogo samoupravleniya $\mathrm{v}$ antibolshevistskom lagere na vostoke Rossii (seredina 1918-konets 1922 G.),” 132; A. V. Semenov, Dal'sovnarkom, 1917-1918 gg.: sbornik dokumentov i materialov (Khabarovsk, 1969), 56, 78-81, 86, 88, 90-91, 127; Tsypkin, Shurygin, and Bulygin, Oktiabr'skaia revoliutsiia i grazhdanskaia voina, 48-51.

37. RGIA DV, f. R-919, op. 1, d. 6, 1.10-12 (A. M. Krasnoshchekov, The October Revolution, the Civil War, and the struggle against foreign intervention in the Far East, 1917-1922, dictated to A. N. Gelasimova in 1932); Semenov, Dal'sovnarkom, 112-13, 115, 118-28, 153; Tsypkin, Shurygin, and Bulygin, Oktiabr'skaia revoliutsiia i grazhdanskaia voina, 51-63. 
Soviets (Petrograd, January 10-18, 1918) - which proclaimed both a federation of national republics and a federation of soviets-as the basis for action. The federation of soviets seemed to imply the right to regional self-determination in line with Iosif Vissarionovich Stalin's early program article, in which he favored the regionalist approach to decentralization. ${ }^{38}$

Although Krasnoshchekov's blueprint for the Soviet Republic of the Far East-if it existed at all, since the name was used only in the mentioned resolution-is nowhere to be found, the available materials of the Far Eastern Council of People's Commissars (Dal'sovnarkom) and Krasnoshchekov's later statements allowed reconstructing the overall design of the distinct Far Eastern regional polity. Krasnoshchekov welcomed neither the alternative Bolshevik regionalisms of Tsentrosibir' and the Amur Republic nor the independent activities of local self-government bodies, which included many SRs and Mensheviks. On Krasnoshchekov's initiative, the Khabarovsk congress resolved to disband the zemstvo and substitute it with soviets of rural deputies. Dal'kom also renamed itself Dal'sovnarkom on May 8, 1918. Krasnoshchekov remained its Chairman and became Commissar for Foreign Affairs. Even though Dal'sovnarkom did not openly defy the Amur Republic, it resolved to abolish oblasts within the Russian Far East. ${ }^{39}$

Krasnoshchekov later claimed that Dal'sovnarkom opposed the Siberian "Oblastnichestvo" of Tsentrosibir' and ensured full subordination of the Amur, Maritime, Sakhalin, and Kamchatka Oblasts to Moscow. ${ }^{40}$ In practice, however, this was not the case. In May 1918, for instance, Dal'sovnarkom received a telegram from the Moscow authorities that explicitly forbade all local bodies to engage in nationalizations but continued to sanction local nationalizations in the Far East. The same month Dal'sovnarkom openly defied Tsentrosibir' rejecting its suggestion of "closer cooperation." 11

Well ahead of the formation of Comintern in 1919 and Moscow's increased attention to Asia since 1920, Dal'sovnarkom attempted to make the Soviet Far East an outpost of the World Revolution in East Asia. It eliminated discriminatory passport restrictions, making Chinese and Koreans without Russian citizenship equal to other foreigners. The land redistribution, which Dal'kom had already begun including allotments to Koreans, to the considerable distress of the Cossacks and the old settlers (starozhily), demonstrated that Krasnoshchekov imagined the Soviet Far East as not exclusively Russian. ${ }^{42}$

38. I. V. Stalin, "Marksizm i natsionalnyi vopros (1913)," in Sochineniia, vol. 2 (Moscow, 1946), 290-367; Tretii Vserossiiskii s'ezd Sovietov rabochikh, soldatskikh i krest'ianskikh deputatov (Peterburg, 1918), 90-94; Mark Vishniak, "Bol'shevizm i Demokratiia," in Bol'sheviki u vlasti: Sotsial'no-politicheskie itogi oktiabr'skogo perevorota (Petrograd, 1918), 85-106.

39. Semenov, Dal'sovnarkom, 131, 137-52, 171-75.

40. RGIA DV, f. R-919, op. 1, d. 6, 1. 6, 12, 16-17 (A. M. Krasnoshchekov, The October Revolution, the Civil War, and the struggle against foreign intervention in the Far East, 1917-1922, dictated to A. N. Gelasimova in 1932).

41. Semenov, Dal'sovnarkom, 178-79, 181-82, 185; Tsypkin, Shurygin, and Bulygin, Oktiabr'skaia revoliutsiia i grazhdanskaia voina, 64.

42. Hopkirk, Peter, Setting the East Abalze: Lenin's Dream of Empire in Asia (London, 1984); Stephan, The Russian Far East: A History, 114-15, 117-18; Tsypkin, Shurygin, and Bulygin, Oktiabr'skaia revoliutsiia i grazhdanskaia voina, 55-62. 
The policy of integrating East Asian minorities and the attempts to establish relations with Chinese authorities were emblematic of Dal'sovnarkom's slogans of solidarity with Koreans and Chinese in opposition to Japanese imperialism. At the same time, its policies heralded the Soviet "new imperialism" of exporting the revolution through client organizations. In May 1918, Krasnoshchekov fostered the creation of the Union of Korean Socialists of thirteen people under Aleksandra Petrovna Kim and Yi Dong-hwi. Dal'sovnarkom nevertheless did not attract broad Chinese or Korean backing. The Union of Korean Socialists mainly relied on political immigrants who were barely integrated into the regional economy and politics, while the majority of Korean activists, many of them being Russian citizens, preferred to side with the SRs. ${ }^{43}$

Although Moscow treated Dal'sovnarkom as a regional Soviet authority, it never recognized the Soviet Far East as autonomous. The Civil War, however, stimulated further decentralization. The revolt of the Czechoslovak Legion (the former Austro-Hungarian prisoners of war who volunteered against their empire and after the Soviet peace with the Central Powers were en route to the Western Front via Siberia and the port of Vladivostok), the renewed offensives under Semenov, Kalmykov, and other anti-Bolshevik leaders, and the full-scale Allied Intervention virtually cut off the Soviet Far East from Moscow, making it de facto autonomous in the summer of 1918. Dal'sovnarkom and the Amur Republic issued their own currencies, which were informally called krasnoshchekovki and mukhinki. Furthermore, Dal'sovnarkom managed to ensure the formation of a military command independent from Tsentrosibir'. ${ }^{4}{ }^{2}$ Over the summer and early fall of 1918, however, Tsentrosibir', Dal'sovnarkom, and all other Soviet authorities in the region were overthrown.

Anti-Bolsheviks also continued to appeal to regionalism. After the Czechoslovaks disbanded the Vladivostok Soviet on June 29, 1918, the city became the seat of Derber's Provisional Government of Autonomous Siberia. Zemstvo and municipal self-governments resumed their activities, while the SR Aleksandr Semenovich Medvedev (who chaired the Maritime Oblast Zemstvo Administration featuring Rusanov) took over as Maritime Oblast Commissar. Many anti-Bolsheviks, however, did not recognize the socialist Siberian government in Vladivostok. In late June 1918, a much more conservative Provisional Siberian Government formed in Omsk under Petr Vasil'evich Vologodskii. On July 9, 1918, General Khorvat arrived at Grodekovo from Harbin and, appealing to his status as the last remaining Commissar of the Provisional Government, proclaimed himself Provisional Supreme Ruler of Russia there. Khorvat's government became the third anti-Bolshevik government that claimed the whole of Siberia. Although the Provisional All-Russian Government (the Ufa Directory) was formed in September 1918 as an antiBolshevik coalition, the conservative Omsk government under Vologodskii (one of the Directory's members) practically substituted its apparatus. Having

43. S. D. Anosov, Koreitsy v Ussuriiskom krae (Khabarovsk, 1928), 19-21; Haruki Vada and Kirill Kirillovich Shirinia, VKP(b), Komintern i Koreia, 1918-1941 gg. (Moscow, 2007), 5.

44. B. I. Mukhachev, Aleksandr Krasnoshchekov: Istoriko-biograficheskii ocherk (Vladivostok, 1999), 79. 
received international backing, Vologodskii ensured peaceful abolition of alternative anti-Bolshevik governments in the Far East. ${ }^{45}$

The Aleksandr Vasil'evich Kolchak coup on November 18, 1918, nevertheless deepened the splits among Siberian Oblastniki. Some of them, like Vologodskii, continued to cooperate with the dictator. Others, like Iakushev, joined the anti-Kolchak opposition in local self-government bodies. The socialist opposition consolidated during zemstvo and municipal congresses in Irkutsk in October-November 1919, entrusting the newly-formed coalitional Political Center under the SR Florion Florionovich Fedorovich to lead an armed uprising. ${ }^{46}$

Appealing to defensive nationalism, the Political Center sought to achieve peace with Soviet Russia ending the Civil War and the Allied Intervention but at the same time aspired to establish a democratic regime in Siberia continuing the SR-Oblastniki trend of $1917-18 . .^{47}$ It did not, however, have solid backing among the workers and urban poor who favored the Bolsheviks. As a result, it presented the Siberian state to the Bolsheviks as a mere "buffer" designed to oust Japan from the Russian Far East rather than a self-sufficient democratic polity. ${ }^{48}$

Semenov also challenged Kolchak's authority. Together with several Buryat-Mongol politicians who objected to the Omsk government's disregard for national self-determination, he attempted to create a unified Mongol state in February 1919. Despite the fact that the Japanese command on site backed Semenov, Tokyo did not support the formation of a Mongol "buffer," and Semenov recognized Kolchak in May 1919.49

Semenov, Kalmykov, and other warlords east of Baikal were notorious for their violence and contributed to the plummeting popularity of the Omsk government. In late December 1919-early January 1920, the Kolchak government collapsed under the attacks of the Red Army advancing from European Russia and due to the uprisings in the rear. In the Yakutsk Oblast, the Bolsheviks and their allies established a Soviet government, but in Irkutsk it was the Political Center that took over in early January 1920. Still, Kolchak transferred his authority in the "Russian Eastern Periphery" to Semenov on January 4, 1920. Vasilii Georgievich Boldyrev, a former member of the Ufa Directory who spent much time with the Japanese command in Tokyo in 1919, noted that an

45. RGIA DV, f. R-786, op. 1, d. 5, 1. 8 (To the Commission of the Far Eastern Regional Committee for the Liquidation of the Maritime Zemstvo from the Olga Uezd Zemstvo Administration, June 5, 1918); G. Ia. Trigub, "Mestnoe samoupravlenie na Dal'nem Vostoke Rossii v period grazhdanskoi voiny i interventsii," Oikumena, no. 3 (2007): 64-67; Tsypkin, Shurygin, and Bulygin, Oktiabr'skaia revoliutsiia i grazhdanskaia voina, 68, 70, 73, $77-78,80,87$.

46. M. V. Shilovskii, Politicheskie protsessy $v$ Sibiri $v$ period sotsialnykh kataklizmov 1917-1920 gg. (Novosibirsk, 2003).

47. Iakushev participated in organizing an anti-Kolchak uprising in Vladivostok in the fall of 1919, but it failed.

48. I. V. Bersneva, “Irkutskoe vosstanie kontsa 1919-nachala 1920 gg.,” Rossyskie sotsialisty i anarkhisty posle oktiabria 1917 goda, at http://socialist.memo.ru/firstpub/ y04/bersneva.htm (last accessed April 24, 2016).

49. Ivan Sablin, Governing Post-Imperial Siberia and Mongolia, 1911-1924: Buddhism, Socialism and Nationalism in State and Autonomy Building (Milton Park, 2016), 106, 115-46. 
independent Siberian state was certainly of interest to both military and civil elites there. Such a state opened a way for Japanese economic imperialism without the need to face military and international consequences of direct occupation. ${ }^{50}$

\section{Political Institutionalization, 1920-1926}

The presence of Japanese troops along the Trans-Siberian Railway between Baikal and the Pacific established a de facto boundary between the Russian Far East and Siberia, "returning" the Transbaikal Oblast to the former. Despite the widespread guerilla slogan of continuing struggle for Soviet rule, Krasnoshchekov managed to convince the Moscow leadership to create a buffer state between Soviet Russia and Japan. He combined defensive nationalist arguments with his own regionalist program in the project of the FER.

During the negotiations between the Political Center and the Soviet authorities in Tomsk on January 19, 1920, the former presented the democratic Siberian Republic to the Bolsheviks as a temporary buffer state that would use the antagonism between the USA and Japan in breaking Soviet Russia's diplomatic isolation and keeping Russia's unity. ${ }^{51}$ The Bolsheviks provisionally agreed to create such a state and awaited approval from Moscow. The very next day, however, a Bolshevik coup ousted the Political Center in Irkutsk. ${ }^{52}$ The Bolsheviks nevertheless kept the plan for a buffer state after Lenin's and Lev Davidovich Trotskii's approval. Krasnoshchekov, as its most vocal supporter, redefined the projected state in line with his earlier policies. It was not a Siberian but the Far Eastern buffer that appealed to his regionalism. He claimed that the state would rely "on local traditions" of decentralization manifested by both zemstvo and Dal'sovnarkom. Krasnoshchekov excluded Irkutsk from the buffer since it was not part of the "Far Eastern federation" that he envisioned within a federative Soviet republic in 1917-18..$^{3}$

Yet the idea of a buffer state east of Baikal met with considerable opposition among the Bolsheviks, and the Political Bureau (Politbiuro) of the Bolshevik Central Committee (TseKa) had to enforce its creation. ${ }^{54}$ The Moscow leadership envisioned the new state as a dependency of Soviet Russia but left the

50. V. G. Boldyrev, Direktoriia, Kolchak, interventy: Vospominaniia iz tsikla "Shest' let" 1917-1922 gg. (Novonikolayevsk, 1925), 170-71, 188, 536.

51. GARF, f. R-341, op. 1, d. 86, 1. 29-32 rev. (Report of the joint meeting of the Peace Delegation of the Political Center with Revvoensovet of the Fifths Army and Sibrevkom, January 19, 1920).

52. GARF, f. R-341, op. 1, d. 92, 1. 2 (The Act of Transferring Authority from the Political Center to the Revolutionary Military Committee, January 22, 1920).

53. GARF, f. R-341, op. 1, d. 86, 1.1-6 (Minutes of the meeting of the Peace Delegation of the Political Center with the representatives of Sibrevkom and Revvoensovet of the Fifths Army, Krasnoyarsk, January 24, 1920). It is unclear if there were any national units to be included into the Far Eastern federation. Most likely, it was to be a federation of Far Eastern regions.

54. Russian State Archive of Social and Political History, (hereafter RGASPI) f. 372, op. 1, d. 5a, 1. 1, paper inlay (Dal' buro of the RCP on establishing connection to its Vladivostok part). 
issue of its political system open to regional leaders. In March 1920, Soviet troops and the former troops of the Political Center took Verkhneudinsk, which was to become the center of the buffer state. ${ }^{55}$

In the meantime, moderate socialists still hoped for a coalitional socialist government. Following the coup against Kolchak's appointees in the Maritime Oblast on January 31, 1920, SRs, Mensheviks, and Bolsheviks united around Medvedev's Maritime Oblast Zemstvo Administration, which proclaimed itself a provincial provisional government. ${ }^{56}$ The Bolsheviks under Lazo planned to establish control over the new Vladivostok government and subdue it to Soviet Russia. Yet the presence of Japanese troops in the Maritime Oblast complicated the plan. Despite Vladimir Dmitrievich Vilenskii (Sibiriakov), who came to Vladivostok to supervise the evacuation of the Czechoslovaks, convincing the regional Bolsheviks to rally behind Medvedev's government, which proclaimed itself the Provisional Government of the Far East on March 31, 1920, General Ōi Shigemoto launched a full-scale attack against it on April $4-5,1920 .{ }^{57}$

A clash between Japanese troops and Russian, Chinese, and Korean guerillas under the anarchist Iakov Ivanovich Triapitsyn in Nikolayevsk-on-Amur in March 1920 also affected Ōi's decision. ${ }^{58}$ Yet according to the Bolshevik Petr Mikhailovich Nikiforov, who controlled the economic sector of the coalitional Vladivostok government, the Japanese attack was triggered by the opponents of the buffer state in Vladivostok. Moisei Gubel'man and Maria Mikhailovna Sakh'ianova, a Buryat Bolshevik, initiated the reestablishment of the Vladivostok Soviet on April 3, 1920, despite a recent Japanese declaration not to permit Soviet rule. Furthermore, the Japanese command had orders from Tokyo to put an end to the Korean guerilla movement and during the attack arrested numerous Korean politicians and fighters. At the same time, it is still unclear to what extent the attack was directed from Tokyo. In talks with Nikiforov, the diplomatic representative Matsudaira Tsuneo claimed that the cabinet was unable to influence the Japanese command and prevent the clash. The occupation of Northern Sakhalin in the summer of 1920 was, however, sanctioned by the government as retaliation for the massacre in Nikolayevsk-on-Amur. ${ }^{59}$

55. Azarenkov, "Demokraticheskii kompromiss": Ideia "bufera,"34-41.

56. Its official became the Provisional Government of the Maritime Regional Zemstvo Assembly. $529-36$

57. Teruyuki Hara, Shiberia shuppei: Kakumei to kanshō 1917-1921 (Tokyo, 1989),

58. The Japanese defeat in Nikolayevsk-on-Amur was followed by a massacre of almost all Japanese military and civilians and many Russians in the town that became known as the Nikolayevsk Incident. The massacre of prisoners took place in May 1920. In early June 1920, the guerillas burnt down the town, see A. N. Fufygin, "Iakov Triapitsyn i Ivan Andreev-zhertva i palach?,” Vestnik Sakhalinskogo muzeia, no. 8 (2001): 161-81.

59. A military report submitted to Tokyo claimed that the Russian troops in Vladivostok attacked first, see JACAR (Japan Center for Asian Historical Records), C06031160200, pp. 0124-0127 (Secret reports on collision between Japanese and Russian Armies in Vladivostok and Razdolnoye, War Ministry, April 8, 1920). There is no evidence that any such attack was planned by the Bolsheviks, but it could have been one of the numerous clashes that were frequent across the Russian Far East at the time. JACAR, C07060927200, p. 1535 (Report on sending the instructions and regulations concerning the control of the Koreans from Ōi Shigemoto to Tanaka Giichi, March 25, 1920); Paul E. Dunscomb, Japan's Siberian 
Given the intention of the Japanese command to establish a new government free from Bolshevik influence, the attack in the Maritime Oblast seemed to prove Krasnoshchekov right. A Soviet government could not be immediately established in the Far East, while Vladivostok could not become the center of a Bolshevik-controlled buffer state. On April 6, 1920, the First Congress of Toilers of western Transbaikalia (or Baikalia) proclaimed the formation of the FER in Verkhneudinsk. The new republic, headed by Krasnoshchekov, claimed authority over all oblasts of the Russian Far East and the CER Zone but in fact controlled only a narrow strip of land on Baikal's eastern bank. The simultaneous formation of the two pro-Bolshevik Far Eastern governments can be attributed to miscommunication between Verkhneudinsk and Vladivostok, due to Semenov's government in Chita. ${ }^{60}$ It is frequently interpreted, however, as rivalry between two Bolshevik groups within the party's Far Eastern Bureau (Dal'biuro). ${ }^{61}$ The SRs and the Mensheviks rejected the design of a Soviet dependency and refused to join the FER government. ${ }^{62}$ Many guerillas and the FER's own soldiers opposed the buffer. Nationalists demanded Russia's integrity, while radical socialists opposed compromises with the "propertied class" and the interventionists. The proponents of Soviet rule controlled the Amur, Sakhalin, and Kamchatka Oblasts in April 1920.63

The failure to create a coalition government in Verkhneudinsk and the setback in military operations against Chita reinforced the splits among the Bolsheviks on the future of the FER. The aftermath of the attack of April 4-5, 1920, proved beneficial for the Vladivostok government, fueling anti-Japanese sentiment and defensive nationalism. The Japanese lost their popularity even among the "propertied class." ${ }^{4}$ Medvedev's government engaged in forming a much more democratic regime and opted for convening a parliament in order to stop the Civil War and end the Intervention through national consensus. ${ }^{65}$ Semenov attempted to seize the initiative, but Tokyo achieved major

Intervention, 1918-1922: “A Great Disobedience against the People” (Lanham, MD., 2011), 119; P. M. Nikiforov, Zapiski prem'era DVR: Pobeda leninskoi politiki v bor' be sinterventsiei na Dal'nem Vostoke, 1917-1922 gg., ed. V. G. Antonov (Moscow, 1963), 189, 192-94. The authors thank Akifumi Shioya for his kind assistance with the Japanese documents.

60. RGIA DV, f. R-4699, op. 1, d. 69, 1.3-4 rev. (Minutes of the meeting of the Government of the FER, April 19, 1920).

61. M. V. Fuks, "Rol' regional'nykh vlastnykh struktur vo vneshnei politike Sovetskoi Rossii na Dal'nem Vostoke v pervoi polovine 20-ykh godov," Russkii istoricheskii zhurnal, no. 2 (1) (1998), at http://zaimka.ru/soviet/fuchs1_p2.shtml (last accessed March 30, 2018).

62. Azarenkov, "Demokraticheskii kompromiss": Ideia "bufera," 41-42, 45.

63. GANO (State Archive of the Novosibirsk Region), f. P-1, op. 2, d. 42, 1. 19 (Report by the Inspector-Organizer of Military Control under the Military Council of the PRA Chertov to the member of Revvoensovet N. K. Goncharov, March 31, 1920).

64. B. I. Mukhachev, ed., Dal'nevostochnaia respublika: Stanovlenie, bor' ba s interventsiei, fevral' 1920-noiabr' 1922 gg: Dokumenty i materialy, vol. 1, fevral'-noiabr' 1920 gg. (Vladivostok, 1993), 117-18.

65. RGIA DV, f. R-534, op. 2, d. 203, 1. 33-33 rev. (Resolution of the Provisional Government of the Far East of the Maritime Regional Zemstvo Assembly, May 5, 1920). 
concessions from Vladivostok and supported it as the center of an anti-Bolshevik buffer state. ${ }^{66}$

The Bolsheviks, however, were not excluded from the Vladivostok government. A broad socialist coalition featuring Bolsheviks enjoyed considerable success during the elections to the Provisional People's Assembly of the Far East, but it was formally non-partisan peasant deputies who received seventy-five out of 130 seats when the parliament opened in Vladivostok on June 20,1920 . Although only about forty-two percent of the deputies were elected (with the rest being nominated by parties and organizations), the People's Assembly reflected the hopes of many intellectuals for the revival of the democratic process. ${ }^{67}$ Moreover, the parliament allowed for representation of the "propertied class," which made it the only institution of authority during the Russian Civil War featuring Bolsheviks and monarchists.

In the meantime, the Verkhneudinsk government proved more successful in military terms. After being recognized by the Bolsheviks of the Amur Oblast in May 1920, and despite signing a truce with the Japanese command in July 1920, the FER continued to attack Semenov's forces, its troops fighting as guerillas. Furthermore, in August 1920, the Moscow leadership reaffirmed Krasnoshchekov's plan for a formally democratic FER instead of the more radical projects of his opponents. ${ }^{68}$

After the withdrawal of the Japanese from Chita, the Verkhneudinsk government ousted the remaining White forces and moved there in late October 1920. ${ }^{69}$ Krasnoshchekov immediately opened a Conference of Regional Governments of the Far East (Chita, October 28-November 10, 1920), even though only one delegate from Vladivostok (Nikiforov) was present. The Bolshevik-dominated conference adopted a declaration on the unification of the former Russian territory between Lake Baikal and the Pacific together with the CER Zone under a single government based in Chita. The universallyelected Constituent Assembly of the Far East was to finalize the unification. Before that, a government under Krasnoshchekov headed the united FER. In December 1920, the People's Assembly of the Far East in Vladivostok recognized the authority of the FER in the Maritime Oblast thanks to the pro-Bolshevik orientation of the peasant majority. ${ }^{70}$

Krasnoshchekov's plan for the FER featured his earlier vision of the Soviet Far East as the main center of revolutionary activities in East Asia. The Vladivostok Bolsheviks had in fact already established connections to

66. M. P. Malysheva and V. S. Poznanskii, eds., Dal'nevostochnaia politika Sovetskoi Rossii, 1920-1922 gg.: Sbornik dokumentov Sibirskogo biuro TsK RKP(b) i Sibirskogo revoliutsionnogo komiteta (Novosibirsk, 1996), 64; Mukhachev, Dal'nevostochnaia respublika, 165.

67. S. D. Kniazev and O. E. Shishkina, "Izbiratel'naya sistema Dal'nevostochnoi respubliki, 1920-1922: Opyt i znachenie dlia stanovlenia izbiratel'noi sistemy Rossii,” Pravovedenie, no. 4 (2006): 101.

68. RGASPI, f. 17, op. 3, d. 102, 1. 4-4 rev. (Brief Points on the Far Eastern Republic adopted by Politbiuro, August 13, 1920).

69. A large share of the remaining White troops relocated to the Maritime Oblast through the CER Zone.

70. G. Ia. Trigub, “Deiatelnost' Primorskoi oblatsnoi zemskoi upravy v kachestve vremennogo pravitel'stva (ianvar'-dekabr' 1920 g.),” Oikumena, no. 1 (2006): 44-54. 
Chinese and Korean revolutionaries. In April 1920, the Foreign Department of the Vladivostok Bolshevik organization had sent a group under Grigorii Naumovich Voitinskii to Shanghai, which soon became a center of propaganda in Chinese, Korean, and Japanese. ${ }^{71}$

The Congress of the Peoples of the East (Baku, September 1-8, 1920), which included Chinese, Korean, and Japanese delegates, seemingly consolidated the Bolshevik determination to export the revolution to Asia, but there was no single opinion in Moscow concerning which groups to support and how to organize propaganda and military efforts in East Asia. Siding with Krasnoshchekov's opponents, the remaining members of the Vladivostok Foreign Department relocated to Irkutsk and not to Chita. Personal rivalries accompanied divergent orientations of the Bolsheviks and splits in nationalist movements. In the Korean revolutionary movement, for instance, Krasnoshchekov backed the moderate Shanghai group while Boris Zakharovich Shumiatskii-who led Tsentrosibir' in 1917 and lost to Krasnoshchekov in the struggle for leadership in the FER in the summer of 1920-supported the radical Irkutsk group. Even though Krasnoshchekov and his allies hampered Irkutsk's communication with the Comintern agents in East Asia in their attempts to make the FER the center of the Bolshevik "new imperialism" in the region, the Moscow leadership established the Far Eastern Secretariat of the Comintern in Irkutsk and not in Chita on January 15, 1921. Furthermore, it was Shumiatskii who headed it. ${ }^{72}$

Although Krasnoshchekov did not make the FER the center of the Bolshevik "new imperialism" in East Asia, he managed to retain his control over the republic at the Constituent Assembly of the Far East, which convened in early 1921. None of the deputies questioned the special status of the Far East, which was then understood as clearly distinct from Siberia. The Constitution of the FER, adopted on April 27, 1921, made the Russian Far East politically and economically different from Soviet Russia by granting its citizens wide political rights and freedoms, establishing a multi-party system, and introducing a state capitalist economic system. ${ }^{73}$ In territorial terms, the FER continued to claim the Russian Far East between Baikal and the Pacific and the CER Zone, but ceded the Kamchatka Oblast to Soviet Russia. The cession of Kamchatka, where Moscow planned to establish concessions for Americans, caused major protests among non-Bolshevik deputies. ${ }^{74}$

Despite its seemingly democratic character, the FER had a centralized system of government dominated by Krasnoshchekov. Such a political system led to outspoken criticism among non-Bolsheviks. Due to the continued Japanese

71. Bruce A. Elleman, Diplomacy and Deception: The Secret History of Sino-Soviet Diplomatic Relations, 1917-1927 (Armonk, NY, 1997), 66-67.

72. Heng-yu Kuo, VKP (b), Komintern i natsional'no-revoliutsionnoe dvizhenie $v$ Kitae: dokumenty, vol. 1: 1920-1925 (Moscow, 1994), 53-55; Vada and Shirinia, VKP(b), Komintern i Koreia, 1918-1941 (Moscow, 2007), 6-11, 76-93, 96-103.

73. Osnovnoi zakon, Konstitutsiia Dal'nevostochnoi respubliki: Utverzhden uchreditel'nym sobraniem Dal'nego Vostoka 27 aprelia 1921 gg. (Chita, 1921).

74. The protests probably reflected the hopes of some moderate socialist that the FER would be independent or at least fully autonomous from Soviet Russia, B. I. Mukhachev, ed., Istoriia Dal'nego Vostoka Rossii ot epokhi pervobytnogo obshchestva do kontsa XX veka, tom 3, kniga 1: Dal'nii Vostok Rossii v period revoliutsii 1917 goda i grazhdanskoi voiny (Vladivostok, 2003), 394-95. 
presence, the southern Maritime Oblast remained outside Chita's direct military control. On May 26-27, 1921, a Semenov-sponsored coup in Vladivostok led to the formation of an alternative political project, the Provisional Priamur Government under the conservative businessman Spiridon Dionis'evich Merkulov. ${ }^{75}$

This setback notwithstanding, the Bolshevik "new imperialism" enjoyed its first success in Asia. The Bolsheviks Ivan Nikitich Smirnov and Shumiatskii, in charge of Soviet Siberia and the Comintern's Far Eastern Secretariat, respectively, suggested that an operation against Roman von Ungern-Sternberg, a former subordinate of Semenov who since January 1921 controlled parts of Mongolia, could be used for occupying the border areas of Mongolia and proclaiming Mongolian independence under a client government. ${ }^{76}$ Krasnoshchekov also supported the operation, but for him it was to become a demonstration that the FER was a regional power despite the Vladivostok coup: he did not agree to Mongolia's independence from China. ${ }^{77}$ In late May-early June 1921, Ungern launched an attack against the FER, and, following a Politbiuro sanction, the troops of Soviet Russia, the FER, and a government formed by the Mongolian People's Revolutionary Party pursued his forces to Mongolia, taking Urga on July 6, $1921 .^{78}$

The Comintern's activities also contributed to the formal establishment of the Communist Party of China by Chen Duxiu and others in Shanghai in late July-early August 1921. Furthermore, on August 14, 1921, the All-Tuvan Constituent Congress proclaimed the independence of Tannu-Tuva, marking the second and final success in exporting the revolution before the Second World War. ${ }^{79}$ It was, however, Siberian Bolsheviks rather than Krasnoshchekov who led these operations, with Chita being denied the status of the center of Soviet revolutionary activities in East Asia.

Krasnoshchekov nevertheless attempted to make decisions independently from Moscow. Despite Moscow's directives that Chita had to discuss all foreign policy matters with it, Krasnoshchekov entrusted Deputy Minister of Foreign Affairs of the FER Innokentii Serafimovich Kozhevnikov to negotiate with the Japanese in Harbin in the summer of 1921. On Krasnoshchekov's approval,

75. Semenov himself was ousted by other anti-Bolsheviks. Mukhachev, Istoriia Dal'nego Vostoka, tom 3, kniga 1, 503-7. $208-12$

76. Malysheva and Poznanskii, Dal'nevostochnaia politika Sovetskoi Rossii, 204-5,

77. Krasnoshchekov probably still hoped to sign a treaty with Beijing. RGASPI, f. 372, op. 1, d. 54, 1. 77-79 (Minutes No. 65 of Dal' biuro, the Administration, and the members of the Revvoensovet of the Fifths Army, June 1, 1921).

78. V. O. Daines, T.F. Kariaeva, M.V. Stegantsev, eds., Shli divizii vpered, 1920-1921: Narodno-revoliutsionnaia armiia $v$ osvobozhdenii Zabaikal'ia: Sbornik dokumentov (Irkutsk, 1987), 265-66, 293; Malysheva and Poznanskii, Dal'nevostochnaia politika Sovetskoi Rossii, 260.

79. The proclamation of Tuvan independence was fostered by the Bolshevik Innokentii Georgievich Saf'ianov, much to the distress of Shumiatskii, who viewed Tannu-Tuva's inclusion into Mongolia as a means of ensuring good relations with Mongolian nationalists. Malysheva and Poznanskii, Dal'nevostochnaia politika Sovetskoi Rossii, 304; Sablin, Governing Post-Imperial Siberia and Mongolia, 1911-1924: Buddhism, Socialism and Nationalism in State and Autonomy Building, 169-70. 
Kozhevnikov signed an agreement for a forest concession in the Maritime Oblast, then partly under the Priamur government, with the Japanese company Mitsui, of which Moscow was informed only in the second half of July 1921. It was this attempt to make the FER autonomous from Moscow that became the turning point for Krasnoshchekov's career and resulted in his recall from the region. On July 20,1921, Dal'biuro annulled the agreement with Mitsui, and on August 3, 1921 rejected Kozhevnikov's initiatives for rapprochement with Japan before it withdrew its troops. ${ }^{80}$

Krasnoshchekov was substituted with the more loyal Nikolai Matveev. The new Chita government used the offensive of the Provisional Priamur Government in late 1921 as cause for dismantling remaining political compromises. Major violations of the FER Constitution followed with the new laws reestablishing the death penalty and limiting the freedom of press. The multi-party system was practically abolished after most of the SRs and Mensheviks were arrested in the summer and fall of 1922. In October 1922, the FER defeated the Priamur State Formation. ${ }^{81}$ On November 14, 1922, the second People's Assembly of the FER proclaimed Soviet rule in the Far East and pled the All-Russian Central Executive Committee (VTsIK) to join the RSFSR. On November 15, 1922, the VTsIK sanctioned the formation of the Far Eastern Oblast. ${ }^{82}$

The FER was abolished mainly due to the changes in the international situation-the diplomatic isolation of Japan at the Washington Naval Conference of 1921-1922 and the limited recognition of the Soviet government at the Genoa Conference in the spring of 1922. Yet the fact that the members of the Bolshevik TseKa were still unsure about the republic's future place in the emerging Soviet structure in September 1922 hints that regionalism remained important despite Krasnoshchekov's resignation. Iakov Davidovich Ianson and Nikolai Afanas'evich Kubiak, who controlled Dal' biuro in the summer of 1922, drafted the plan for the FER's integration, which was discussed in Moscow in September 1922. The draft stressed special economic and political conditions in the FER and contained a suggestion to transform it "into a Soviet republic." 83 The secret directive of the Politbiuro, adopted on September 21, 1922, did not include the idea of creating a separate Far Eastern Soviet republic, if this was what Dal'biuro meant, yet cautioned against the immediate Sovietization of the FER. ${ }^{84}$

The decision to annex the FER to the RSFSR through the People's Assembly was made only in October 1922, after the breakup of talks with the Japanese

80. Fuks, "Rol' regional'nykh vlastnykh struktur."

81. For more on the Priamur State Formation, see Ivan Sablin, "Nationalist Mobilization in the Russian Far East during the Closing Phase of the Civil War," Vestnik of Saint Petersburg University: History 62, no. 1 (2017): 18-25; Iu. N. Tsipkin, Grazhdanskaia voina na Dal'nem Vostoke Rossii: Formirovanie antibol'shevistskikh rezhimov i ikh krushenie: 1917-1922 gg., (Khabarovsk, 2012).

82. A. A. Azarenkov, "Metody likvidatsii Dal'nevostochnoi respubliki v 1922 godu," Voprosy Istorii, no. 8 (2006): 94-104.

83. RGASPI, f. 17, op. 112, d. 366, 1. 63-64 (Minutes No. 51 of Orgbiuro of TseKa RCP(b), September 4, 1922).

84. RGASPI, f. 17, op. 163, d. 296, 1. 41-42 (Minutes No. 27 of Politbiuro of TseKa RCP(b), September 21, 1922). 
and their unilateral withdrawal from the mainland Russian Far East. Dal' biuro agreed to immediate annexation of the FER but delayed its rapid integration into the Soviet system, put forward by Stalin, opting instead for the creation of a transitional Far Eastern Revolutionary Committee (Dal'revkom). Ianson stressed the need for gradual Sovietization due to the major differences in the economies of the RSFSR and the FER and received approval from the TseKa. ${ }^{85}$

Although a Far Eastern republic did not fit into the ethno-national approach towards federalism that substituted Stalin's initial openness to regionalism, Dal'revkom's supreme regional authority made the Far Eastern Oblast consisting of guberniias a de facto autonomous macro-region. The Japanese occupation of Northern Sakhalin that ended only in 1925 played a major role in the special status of the Russian Far East, but Dal'revkom found other reasons for the delayed integration into the RSFRS. Petr Alekseevich Kobozev, its first chairman, stressed the lack of support for the Bolsheviks among the regional, mainly peasant, population and the "backwardness" of the Far East compared to the rest of North Asia. Although he favored the "harshest methods of proletarian dictatorship" as a means of developing the "colony," he also spoke of difference between the Russian Far East and the rest of the country. ${ }^{86}$

Kobozev's radicalism did not find support in the party and he soon resigned. Contrary to his suggestions, the Far Eastern Oblast-which since 1922 included the Kamchatka Guberniia and since 1923 excluded the newly formed Buryat-Mongol Autonomous Socialist Soviet Republic (BMASSR)retained some laws and institutions of the former FER, like the Far Eastern Bank. Furthermore, Koreans who had no national autonomy formed national self-government bodies, which was not envisioned by the Soviet constitution. ${ }^{87}$

Ian Borisovich Gamarnik, who chaired Dal'revkom since 1923, defended the integrity of the Far East as a distinct and autonomous unit. On May 19 and 27, 1925, a few days after the Japanese withdrawal from Northern Sakhalin, Gamarnik appealed to the Moscow leadership to retain the broad competence of Dal'revkom. Gamarnik explained the need for "autonomy" in financial and economic questions through the peculiarities of the region's geographical remoteness, which remained a "terra incognita" for Moscow; the efficiency of the semi-independent financial policies that made the Far East profitable during Soviet times in contrast to the Tsarist period; and the importance of economic connections to the neighboring countries-all of which appealed to Far Eastern regionalism. ${ }^{88}$

Moscow, however, rejected the appeals and on January 4, 1926, the Far Eastern Oblast was transformed into the Far Eastern Krai, which was fully integrated into the RSFSR. Reporting to the first Congress of Soviets of the Far

85. RGASPI, f. 372, op. 1, d. 138, 1. 33 (From Stalin to Sapronov, October 1922); 1. 36-38 rev. (Meeting of the members of Dal' biuro, October 28, 1922); 1. 39 (From Sapronov to Stalin, October 30, 1922).

86. N. I. Riabov, ed., Dal'revkom: Pervyi etap mirnogo sovetskogo stroitel'stva na Dal'nem Vostoke, 1922-1926 gg.: Sbornik dokumentov (Khabarovsk, 1957), 90-92.

87. N. I. Dubinina, "O proektakh sotsial'no-ekonomicheskogo razvitiia Sovetskogo Dal'nego Vostoka v 1920-30-e gody,” Stranitsy istorii, no. 4 (2011): 113-18.

88. RGIA DV, f. R-2422, op. 1, 467, 1. 3 (From Gamarnik to Boguslavskii, May 19, 1925); 1. 8 (From Gamarnik to Rykov, May 27, 1925). 
Eastern Krai on March 17, 1926, Gamarnik summed up the process of "unifying" the Russian Far East by stressing the success of Dal'revkom in saving it from becoming a colony of the imperialists and underlining the need to continue Russian settler colonization. He also claimed that the formation of the Far Eastern Krai broke the supposedly artificial old Tsarist boundaries and institutionalized the Far East as a single whole. ${ }^{89}$ In this respect his regionalism returned to the defensive nationalist discourse of the State Duma deputies' dropping all "new imperialist" connotations.

Russian nationalism prevailed in the administration of the Soviet Far East. The leadership of Dal'revkom proved especially reluctant to support minority nationalist claims. They vigorously opposed the creation of the BMASSR and ensured that no permanent autonomy was established for Koreans. This corresponded to the eclipse of the principle of World Revolution by Socialism in One Country. In 1925, the Comintern's executive body resolved that the operations related to East Asian revolutionary movements were to be moved abroad..$^{90}$

On January 5, 1926, the day after the VTsIK established the Far Eastern Krai, a meeting under the People's Commissariat of Foreign Affairs of the USSR resolved that it was necessary to stop the "inflow" of Chinese and Koreans into Soviet territory. On May 10, 1926, the Bolshevik Bureau of the Far Eastern Krai Committee resolved to forbid unauthorized arrival of foreigners and permitted their administrative deportation due to the need for land for settlers coming from the European part of the USSR. ${ }^{91}$

The administrative integrity of the Russian Far East did not last. In 1938 the region was split into the Maritime and Khabarovsk Krais. Yet many agencies retained the word Far Eastern in their official names. The region remained in the sphere of governance as the Far Eastern Economic Region (ekonomicheskii raion) of the USSR. The constantly shifting approaches to the Russian Far East, which since the annexation of the Amur and Ussuri territories vacillated between the need for better integration into international trade and resource development on the one hand and the fear of losing it to foreign governments on the other, were settled by Stalin, who opted for forced prisoner colonization, international isolation, and ethnic cleansings in the region. With the blossoming of anti-imperialist considerations into outward paranoia, the Chinese and Koreans were forcibly removed from the Russian Far East, while its other inhabitants, including the indigenous peoples, had to resettle away from border areas and, on many instances, away from the coast. In many cases this undermined local economies and in the

89. Riabov, Dal'revkom: Pervyi etap, 232-62.

90. RGIA DV, f. R-2422, op. 1, d. 1487, 1. 110-111 (Minutes of the meeting of the Subcomission on the Soviet Organization of the Korean Commission under Dal'revkom, April 3, 1925); Vada and Shirinia, VKP(b), Komintern i Koreia, 1918-1941 gg., 307, 312.

91. RGIA DV, R-f. 2422, op. 1, d. 1487, 1. 112-120 (Minutes of the meeting of Korean party activists with the participation of representatives from county executive committees and village councils, Vladivostok, June 2, 1925); E. N. Chernolutskaia, Prinuditel'nye migratsii na sovetskom Dal'nem Vostoke v 1920-1950-e gg. (Vladivostok, 2011), 219; Vada and Shirinia, VKP(b), Komintern i Koreia, 1918-1941 gg., 350-51. 
end resulted in numerous casualties, impoverishment of individual communities, and deep economic crisis. ${ }^{92}$

The imagined unity of the Russian Far East, however, outlived the administrative reform and the Soviet system. In 2000 it was re-institutionalized as the Far Eastern Federal District, with the inclusion of Yakutia as part of the former Soviet Far Eastern Economic Region. At the same time, the new administrative reform did not eliminate the economic challenges that the frontier region faced. It still has to be integrated into the Pacific markets, while its resources largely remain outside the Russian economy. In contemporary circumstances of depopulation, emerging environmental challenges, and continuous fears of large-scale immigration from East Asia, the economic development of the Russian Far East remains a problem yet to be comprehended and resolved. The creation of the Ministry for Development of the Russian Far East in 2012 reaffirmed the peculiar status of the Russian Far East and its protracted integration into Russian imperial and post-imperial formations.

92. Chernolutskaia, Prinuditel'nye migratsii na sovetskom Dal'nem Vostoke v 19201950-e gg.; Ivan Sablin, "Rearrangement of Indigenous Spaces: Sovietization of the Chauchus and Ankalyns, 1931-1945," Interventions: International Journal of Postcolonial Studies 16, no. 4 (2014): 531-50. 